\title{
Sektörel Ăg Analizi: Huğlu-Üzümlü Av Tüfeği Sanayisi Üzerine Bir Saha Araştırması (Sectorial Network Analysis: A Field Study on Huğlu-Üzümlü Shotgun Industry)
}

\section{Vildan GÜLPINAR DEMİRCi (iD) a Fatma DİKKAYA iD b}

a Aksaray Üniversitesi, İktisadi ve İdari Bilimler Fakültesi-İktisat, Aksaray, Türkiye, vildangulpinar@aksaray.edu.tr

b Aksaray Üniversitesi, İktisadi ve İdari Bilimler Fakültesi-İktisat, Aksaray, Türkiye, fatma.dikkaya@asu.edu.tr

\section{MAKALE BİLGISI \\ Anahtar Kelimeler: \\ Sosyal A $\breve{g}$ Analizi \\ Av Tüfeği \\ Savunma Sanayisi \\ Huğlu \\ Üzümlü}

Gönderilme Tarihi 2 Ekim 2020

Revizyon Tarihi 1 Şubat 2020

Kabul Tarihi 7 Mart 2021

Makale Kategorisi:

Araştırma Makalesi

\section{ÖZET}

Amaç - Av tüfeği üretiminden, savunma sanayisi üretimine geçişte; Huğlu-Üzümlü bölgesinde yer alan av tüfeği sektöründeki işletmelerin durumunu değerlendirmek, Sosyal A $\breve{g}$ Analizi (SAA) yardımıyla ilişki ağını görselleştirip, sektörün önemli aktörlerini ortaya çıkarmaktır.

Yöntem - Araştırmada ilişkisel tarama modelinden yararlanılmıștır. Beyșehir Ticaret Odasına kayıtlı 190 işletmeden 100 tanesi kartopu örneklemesi ile belirlenmiş; veriler, anket ve yarı yapılandırılmış görüşme yardımıyla elde edilmiştir. Bulguların elde edilmesinde SPSS paket programında Mann Whitney U ve Ki-kare bağımsızlık testleri kullanılmıştır. SAA için ise Pajek programı kullanılmıştır.

Bulgular - Araştırma sonuçlarına göre, işletmelerin yüzde 40'ı bölgedeki iş birliği düzeyini iyi ya da çok iyi düzeyde görürken, iş birliğini yetersiz olarak değerlendiren sadece yüzde 12 düzeyinde işletme bulunmaktadır. Kurumlar arası iş birliğinin önündeki en önemli engeller ise birbirlerine çok yakın oranlarla finansal kaynakların kısıtlılığı, kişisel çıkarların kurumsal vizyonun önüne geçmesi ve temel düşünce ayrılıkları olarak sıralanabilir. Sosyal ağ merkezilik ölçülerine göre ise; Huğlu Av Tüfekleri Kooperatifi hem derece hem de yakınlık merkeziliği en yüksek işletme olarak ağda en güçlü aktör konumundadır. Sosyal ağdaki en güçlü aracı aktör ise Yüztek Yüzey Teknolojileri olarak görülmektedir.

Tartışma - İş birliği önündeki engellerin giderilmesinde özellikle bir ihtisas organize sanayinin kurulması, böylece kurumlar arası fiziksel ve iletişim kaynaklı sorunların çözülerek, daha güçlü bir ağın elde edilmesi önerilmektedir. Araştırmada klasik sektör değerlendirmelerine ek olarak, iş birliği ağlarının incelenmesinin avantajları gösterilmiştir.

\section{ARTICLE INFO}

\section{Keywords:}

Social Network Analysis Shotgun

Defense Industry

Huğlu

Üzümlü

Received 2 October 2020

Revised 1 February 2021

Accepted 7 March 2021

Article Classification:

Research Article

\section{ABSTRACT}

Purpose: The purpose of this article is therefore to assess the status of shotgun enterprises in the Huğlu-Üzümlü Region during transition from shotgun production to defense industry and with the help of SNA, to visualize the relationship network and manifest the major actors in the sector.

Design/Methodology/Approach - The study utilized relational screening model. For this purpose, 100 amongst 190 companies that are registered in the Beyşehir Chamber of Commerce were identified by snowball sampling, and data was obtained through polls and semi-structured interviews. The research hypotheses have been tested with Mann Whitney $U$ and chi-square independence methods. The Pajek program was used for SAA.

Findings: The research results show that 40 percent of companies consider the level of cooperation in the region good or very good. The most important hindrances facing cooperation between enterprises include scarce financial resources, the ratios of which are close to each other, prevalence of personal interests over corporate vision and fundamental differences of opinion. According to standards of social network centricity, Huğlu Av Tüfekleri Kooperatifi represents the strongest actor in the network as a company with the highest degree of proximal centricity. The strongest intermediary actor in the social network appears to be Yüztek Yüzey Teknolojileri.

Discussion: For removing obstacles facing cooperation, it is especially recommended to establish an expert organized industry and therefore, to resolve physical and communication-related problems between institutions and to obtain a stronger network. In addition to traditional sector assessments, the research has also shown the advantages of examining cooperation networks. 


\section{Giriş}

72 ülke tarafından yapılan av tüfeği ihracatının 2018 yılında dünya genelinde 1,1 milyar dolar seviyesinde olduğu bilinmektedir. İhracat pazarında yer alan ilk 15 ülkenin ihracatı toplam av tüfeği ihracatının \%97'sini oluşturmaktadır. 2018 yılı itibariyle dünya av tüfeği ihracat pazar büyüklügünde ilk sırada İtalya yer almaktadır. Dünyada önde gelen av tüfeği ihracatçısı olan İtalya, dünya av tüfeği ihracat pazarının \%26'sına sahiptir ve beş yıllık ihracat değeri ortalaması 300 milyon dolar seviyesindedir. Türkiye, İtalya' dan sonra ikinci sırada yer almaktadır ve dünya ihracat pazarındaki payı \%10'dur. Toplam ihracat hacmi ise 135 milyon dolar seviyesindedir. Dünya ihracat pazarında önemli bir yere sahip olan Türkiye'nin, av tüfeği üretiminin çok önemli bir kısmı Huğlu-Üzümlü bölgesinde yapılmaktadır (ITC, 2020). İtalya'da da tüfek üretiminin büyük bir kısmı, Brescia bölgesinde bir kasabadan yapılmaktadır. Dünyanın ve Avrupa'nın av tüfeği başkenti olarak adlandırılan kasabada 150 işletme vardır ve Avrupa Birliği'nde kullanılan av tüfeklerinin \% $\% 0^{\prime} \mathrm{i}$, dünyada kullanılan av tüfeğinin ise \%40'1 İtalya'da üretilmektedir. Türkiye'de üretilen av tüfeklerinin \%75'i de Huğlu ve Üzümlü bölgesinden sağlanmaktadır. Bölgede Birinci Dünya Savaşı yıllarında başlayan av tüfeği üretimi; coğrafya, uzun yıllara dayanan bilgi birikimi, beceri ve tecrübe gibi faktörler açısından İtalya ile benzerlik göstermektedir (STM ve KOP 2019 Raporu, 2019: 13-15).

On Birinci Kalkınma Planında "milli teknolojiler ve yerli imkânlarla savunma sanayiinde dişa bağımlılığı asgari seviyeye indirecek projelerin hayata geçirilmesi (420. madde)" hedefiyle uyumlu olarak savunma ve havacılıktaki yerlilik oranı 2018'de yüzde 65 iken 2023 hedefi yüzde 75 olarak belirlenmiştir (On Birinci Kalkınma Planı (2019-2023), 2019). 2018'de kurulan Aselsan Konya Silah Sistemleri A.Ş.'den Huğlu-Üzümlü bölgesinde av tüfeği üretimi yapan dört işletme (Huğlu Av Tüfekleri Kooperatifi, Akdaş Makine, Akus Silah Sanayi ve Derya Silah Sanayi) ortaklıktan pay almıştır. Böylece av tüfeğinden savunma sanayisine üretime geçişte önemli potansiyele sahip olan Konya'nın Beyşehir ilçesi daha da önemli bir konuma gelmiştir (STM ve KOP 2019 Raporu, 2019: 17-20).

Konya, tüfek ve özellikle av tüfeği üretiminde merkezi bir noktada bulunmakta olup, üretim il merkezinden çok Beyşehir ilçesinde yoğunlaşmaktadır. Beyşehir'de ilçeye bağlı Huğlu ve Üzümlü kasabalarında kökleri 1914'e kadar uzanan tüfek üretimi, kurulan kooperatifler ile küçük ve orta boy işletmelerden (KOBİ) oluşmakta ve bölgede ticaret odasına kayıtlı 190 işletme bulunmaktadır.

Literatürde, Huğlu ve Üzümlü bölgelerindeki av tüfeği ve yan sanayi üretimi yapan işletmelere yönelik bazı araştırmalar yer almaktadır. Mevcut çalışmaların genelde bölgedeki az sayıda büyük işletmeye odaklandığ 1 ve SWOT analizleriyle sektörün durum değerlendirmesini içerdiği görülmektedir (MEVKA, 2012; Yalçın, 2016; Çalışkan ve Manav, 2014). Bu araştırmada ise daha geniş bir kitle hedef alınmış, büyük işletmelere ek olarak görece daha küçük işletmelerin görüşlerine ve ağ içerisindeki konumlarına da yer verilmiştir. Bu noktadan hareketle toplam 190 işletmeden 100'ünün katılımıyla, anket ve yarı yapılandırılmış görüşme yardımıyla veriler elde edilmiştir. Elde edilen bulgular, bölgedeki ortaklık ve iş birliği ağını göstermesi ve etkili aktörleri ortaya çıkarması açısından önem taşımaktadır. Diğer taraftan ortaklık ve iş birliği kültürünü geliştirmenin önündeki engellerin ve sorunlu alanların tespit edilmesi, sektörün gelecekte yapacağı fiziki ve ticari yatırımların yönünü belirlemek açısından da katkı sağlayacaktır. Son olarak ülkemizde benzer şekilde kümelenmiş sanayi bölgeleri ve sektörler üzerine yapılan araştırmalarda işletmelerin bireysel ya da sektörel verilerine odaklanmanın yanı sıra, ilişki ağlarıyla birlikte değerlendirilmelerinin önünü açmak hedeflenmiştir. Böylelikle, her bir işletme sektörel ağın bir parçası olarak ele alınacak ve ağdaki konumlarına göre değerlendirilebilecektir.

\subsection{Huğlu ve Üzümlü Bölgesinde Av Tüfeği İmalatı}

Sanayi Devrimi ile başlayan ve 19. yüzyıldan sonra önemi daha da artan sanayi sektörünün dünyaya yayılması ile ilk sanayi bölgesi uygulamaları yapılmıştır. Dünyada ilk sanayi bölgesi örneği 1897'de İngiltere'nin Manchester kentinde görülmüştür. Sanayi bölgeleri ülkedeki sanayileşmeyi hızlandırıp, bölgeye iş gücü sağlayarak istihdam gücüne katkı sağlar. Sanayi bölgelerinde işletmeler benzer alanlarda faaliyet gösterdikleri için hem iş birliği hem de rekabet söz konusudur. Rekabet; kalite ve verimliliği arttırarak küçük işletmelerin büyümesine katkı sağlamaktadır. Sanayi bölgeleri işletmelere, ortak emek havuzundan yararlanma, iş birliği ile ham madde alımlarını toplu yaparak taşıma maliyetlerini düşürme, coğrafi yakınlıktan dolayı bilgi alışverişinin hızlı olması, yatay ve dikey olarak ihtisaslaşma başta olmak üzere çok sayıda fayda sağlamaktadır (Cansiz, 2010: 16-18). 
Türkiye'de ilk av tüfeği imalatının yapıldığı yer Huğlu bölgesidir. Bölge, coğrafi koşulları nedeniyle tarım ve hayvancılık için elverişli olmadığından 1950'li yıllarda ilerleme gösteren tüfek üretimi, çevre bölgelere de istihdam olanağı sunmuştur. 1962 yılına kadar bireysel devam eden tüfek imalatı, 16 Kasım 1962 yılında 165 üye ile Huğlu Av Tüfekleri Kooperatifi'nin kurulmasıyla kurumsal bir çatı altında toplanmıştır (Yalçın, 2016; Çalışkan ve Manav, 2014). Günümüzde Huğlu Av Tüfekleri Kooperatifi 548 üye ve 387 çalışanı ile ürettiği tüfeklerin \%80'ini başta ABD olmak üzere 54 ülkeye ihraç etmektedir. Huğlu av tüfekleri kooperatifinde imal edilen Renova adlı av tüfeği, Guiness rekorlar kitabına girmeyi başarmıştır (Yaşar, 2019). Huğlu'da başlayan av tüfeği üretimi, çevresindeki Üzümlü halkını da silah üretimine yönlendirmiştir. Üzümlü ve Huğlu av tüfeği üzerine doğal bir kümelenme oluşturmuşlardır. Bölgede sektöre nitelikli eleman yetiştirmek için 1994'te kurulan Selçuk Üniversitesi Huğlu Meslek Yüksekokulu ve makine teknolojisi alanında ihtisaslaşmış eğitim veren tek tematik meslek lisesi statüsünde yer alan Beyşehir Huğlu Makine Teknolojisi Mesleki ve Teknik Anadolu Lisesi bulunmaktadır. Lisede av tüfeği ve parça üretimi yapan işletmelerle protokoller imzalanmış, sektörün ihtiyaçlarına yönelik alanlarda eğitimler verilerek, sektörün nitelikli eleman ihtiyacı karşılanmaya başlanmiştır.

\subsection{Sosyal A $\breve{g}$ Analizi (SAA)}

1736 yılında Könisgberg köprüleri problemiyle ortaya çıkan ağ bilimi; fizik, matematik ve istatistik başta olmak üzere diğer bilim alanlarının katkılarıyla ilerlemiş, internet teknolojileri ve devamında sosyal ağların yaygınlaşmasıyla günümüzdeki popülaritesine ulaşmışır. Ağ kavramı varlıklar ve varlıklar arası bağlardan oluşur. Ağları tanımlamak için bir varlığa odaklanmak yerine öncelikle genel resme bakıp ağın odağının belirlenmesi gerekmektedir. SAA, insanlar arası fikirler, sosyal roller, iş birliği, arkadaşlık, meslektaşlık gibi herhangi bir sosyal varlık grubu arasındaki karmaşık olan ilişkilerin oluşturduğu sosyal ağ yapılarının çözümlenmesinde, hesaplanmasında ve tahmin edilmesinde kullanılır. A ̆g içerisindeki karmaşık bağların çözümlenebilmesi ve lider aktör ya da işletmeye ulaşılabilmesi için matematiksel gösterimlere ve görselleştirmelere ihtiyaç duyulmuştur. Ağ yapılarındaki birim ya da bireylerin her birine düğüm ve birbiri ile olan ilişkisine de "bağlantı" denir (Delil, 2013; Gülpınar Demirci, 2020).

A $\breve{g}$ yapılarının analiz edilmesini ve yorumlanmasını kolaylaştırmak için bazı matematiksel kavramlar geliştirilmiştir. Bu kavramlardan en sık kullanılan yoğunluk (density) ve merkezilik (centrality) kavramları şu şekilde özetlenebilir:

Yoğunluk: Yoğunluk ağdaki mevcut bağlantı sayısının olası bağlantı sayısına oranıdır (Gürsakal, 2009: 78).

Merkezilik: Merkezilik, "bir ağ içerisindeki düğümün sahip olduğu bağlantılardan dolayı kazandığı önemlilik derecesi" olarak tanımlanabilir. Bir düğümün, ağ içerisinde ne düzeyde merkezi bir konumda bulunduğunun bir ölçüsüdür. Sosyal hayattaki popülerlik kavramı da merkezilik durumuna karşılık gelmektedir. Derece (degree), arasındalık (betweenness) ve yakınlık (closeness) olmak üzere üç tür merkezilik ölçüsü hesaplanmaktadır.

Derece Merkeziliği: Derece merkeziliği bir düğümün diğer düğümlerle olan doğrudan bağlantı sayısı ile ifade edilir. Derece merkezilik özelliği olan bir dügüumün, diğer üyelere göre potansiyel avantajları olan, ağdaki en aktif kişi olduğu söylenebilir (Delil, 2013; Gülpınar Demirci, 2020).

Arasındalık Merkeziliği: Arasındalık merkeziliği bir ağ içerisindeki tüm düğümlerin arasında var olan en kısa yolların sayısı ile hesaplanır. Arasındalık merkeziliği en fazla olan aktör, ağ üzerindeki en güçlü ve en iyi pozisyonun sahibidir ve ağdaki iki ya da daha fazla grubu birbirine bağlayan, aracı aktördür. Arasındalık ağda yayılmak için önemli bir kavramdır (Delil, 2013; Gülpınar Demirci, 2020).

Yakınlık Merkeziliği: Bir düğümün diğer düğümlere ne kadar yakın olduğunu gösterir. Yakınlık merkeziliği yüksek bir aktör, diğer aktörlere erişimde merkeze yakın olduğu için en kısa yollara sahiptir. Üyeler lider olan üyeye ne kadar yakınsa yakınlık merkeziliği değeri o kadar yüksek olmaktadır. Yakınlık merkeziliği yüksek olan aktörler diğer üyelere en hızlı şekilde ulaşabilir, diğer üyelerin en yakınında yer alır ve ağ üzerinde olup bitenlerden en hızlı şekilde haberdar olabilir (Delil, 2013; Gülpınar Demirci, 2020). 


\section{Kavramsal Çerçeve}

Literatürde hem bir sanayi bölgesinin/ sektörün genel özellikleri, ticari potansiyeli, sektörel sorunlar ve çözüm önerilerinin içerildiği hem de SAA ile sektörel ağ analizinin yapıldığı bir araştırmaya rastlanmamıştır. Buna rağmen konuyla ilişkili ülkemizde ve dünyada yapılan araştırmalar Tablo 1'de gösterilmiştir.

Tablo 1. Literatür Özeti

\begin{tabular}{ll}
\hline Kaynak & Araştırmanın Amacı ve Yöntemi \\
\hline Çilingirtürk, & Küçükçekmece'de faaliyet gösteren küçük- \\
(2020) & orta ölçekli işletmeler ile sanayi \\
& kuruluşlarına ait genel durum ve gelecek \\
& beklentilerinin analizi yapılmıştır. 2514 \\
& ticaret, küçük sanayi ve sanayi işletmesi ile \\
& anket görüşmesi yapılmış, elde edilen \\
& verilerle sektörel ağ analizi uygulanmıştır. \\
\hline Rojas, Solis ve & Çalışmada, firmalar ve devlet destekli \\
Zhu (2018) & kurumlar (DDK) arasındaki iki taraflı ağ \\
& yapısı incelenmiştir. Firmaların Ar-Ge \\
& çalışmalarıyla bağlantılı olarak, firma \\
& yenilikçiliği üzerindeki etkilerini incelemek \\
& için SAA tekniklerinden yararlanılmıştır. \\
& Daha sonra bu iş birliği ağlarının etkileri, \\
& sektör içi ve sektörler arası olmak üzere iki \\
& düzeyde karşılaştırılmıştır.
\end{tabular}

\section{Araştırmanın Bulguları ve Sonuçları}

Kentsel dönüşüm sürecini ön görüp, dönüşümün kontrolünü istenen yönde sağlayabilmek için sosyal ağ analizi verileri ile sektördeki kurumların ilişkileri sonucunda ilçedeki sanayi ve ticaret ağı elde edilmiştir. Analiz sonucunda bölgedeki lider işletmeler tespit edilmiştir.

Meksika'daki 420 imalat firmasını kapsayan çalışmada, hem firmalar ve DDK arasında hem de firmaların kendi aralarında oluşturdukları ağların yapısal özelliklerinin yenilikçilik üzerinde olumlu etkileri olduğu tespit edilmiştir. Dolayısıyla firmaDDK ağlarında yüksek merkezilik ve kümelenme katsayısına sahip firmaların, örgütsel faydalarında farklılıklar olmasına rağmen, her ikisinin de üstün yenilikçilik sergilediği görülmüştür.

\begin{tabular}{llcr}
\hline Basole R.C. & Çalışmada & küresel & elektronik \\
(2016) & endüstrisindeki & şirketler & arası iş birliği \\
& ağlarının topolojik özellikleri incelenmiştir.
\end{tabular}

Çalışmada; yüksek performanslı firmaların iş birliği düzeyinin daha güçlü olduğu ve bu firmaların, az sayıda firma ile doğrudan ilişki kurduğu tespit edilmiştir. Yüksek performanslı firmalarla iş birliği yapmak isteyen firmaların; sözleşmeye dayalı ve kısa vadeli ilişkilerden kaçınıp, uzun vadeli ve ilişkisel gücü arttırmaya yönelik çalışmalara odaklanması önerilmiştir. Diğer taraftan firmaların, ortakların kapasite ve yeteneklerinden yararlanabilleri için iş birliği ağlarını sürekli olarak taramaları önerilmekedir.

\begin{tabular}{ll}
\hline Yalçın (2016) & Huğlu bölgesinin tüm ayrıntılarıyla \\
& tanınması, kaynak ve olanaklarının daha \\
& gerçekçi tespiti ve kalkınma açısından daha \\
& iyi planlamaların yapılması amaçlanmış, \\
& SWOT analizi ile desteklenmiştir.
\end{tabular}

2016 yılında Türkiye av tüfeği üretiminin \%70'inin bölgede üretildiği ve dünyaca ünlü marka uzmanı Simon Anholt'un yazdığı kitapta dünyada büyüyen işletmelere Huğlu'yu örnek göstermesine ve basın toplantısında Türkiye'den tanınmış en ünlü üç işletme sorusuna Huğlu'yu da katmasına yer verilmiştir. Bölgenin eksiklikleri tespit edilip çözümlemeleri yapılmıştır. Son kısmında Huğlu'da uygulanabilecek proje önerilerine yer verilmiştir.

\begin{tabular}{|c|c|c|}
\hline $\begin{array}{l}\text { Rasskazov, } \\
\text { Rubtcova ve } \\
\text { Derugin (2016) }\end{array}$ & $\begin{array}{l}\text { Rusya'daki küçük işletmelere sosyal ağ } \\
\text { analizinin uygulanmıştır. }\end{array}$ & $\begin{array}{l}\text { Rusya'daki sektörel ağlar bulunmuş ve bu nicel } \\
\text { göstergelerden yola çıkılarak işletmelerin fırsatları } \\
\text { değerlendirilmiştir. }\end{array}$ \\
\hline $\begin{array}{l}\text { Müderrisoğlu } \\
\text { ve Gezici } \\
\text { Korten }(2015)\end{array}$ & $\begin{array}{lllr}\text { Çalışmanın } & \text { amacı } & \text { mekânsal } & \text { yakınlığın } \\
\text { aktörler } & \text { arası } & \text { ilişkilere } & \text { etkisinin } \\
\text { ölçülmesidir. Bu doğrultuda } 57 & \text { işletme ile } \\
\text { anket görüşmesi yapılmıştır. } & \end{array}$ & $\begin{array}{l}\text { İstanbul Dudullu bölgesinde } \\
\text { çalışmada mobilya kümelenmesi incelenteştirilen } \\
\text { mekânsal ve } \\
\text { doğrulanmıştır. }\end{array}$ \\
\hline $\begin{array}{l}\text { Manav ve } \\
\text { Çalışkan (2014) }\end{array}$ & $\begin{array}{l}\text { Çalışmada Huğlu silah sanayisinin tarihsel } \\
\text { gelişimi ve bu gelişmelerde etkili olan } \\
\text { coğrafi faktörlerin açılanması amaçlanmış } \\
\text { ve bu doğrultuda } 10 \text { işletme ile yüz yüze } \\
\text { anket görüşmesi ardından SWOT analizi } \\
\text { yapılmıştır. }\end{array}$ & $\begin{array}{l}\text { SWOT analizi sonucunda gerekli destekle bölgenin } \\
\text { savunma sanayisine üretime geçilebileceği sonucuna } \\
\text { ulaşılmıştır. }\end{array}$ \\
\hline
\end{tabular}




\begin{tabular}{|c|c|c|}
\hline Delil (2013) & $\begin{array}{l}\text { TRC2 (Diyarbakır-Şanlıurfa) bölgesindeki } \\
\text { işletmelerin iş birliği düzeylerinin tespiti } \\
\text { amaçlanmaktadır. } \mathrm{Bu} \mathrm{doğrultuda} 480 \\
\text { işletme ile anket görüşmesi ardından ağ } \\
\text { analizi yapılmıştır. }\end{array}$ & $\begin{array}{l}\text { Sektörler arası ağın elde edildiği çalışmada, iki ili } \\
\text { birbirine bağlayan tek kurumun Kalkınma Ajansı } \\
\text { olduğu belirtilmiştir. A } \breve{g} \text { analizi sonucunda iki } \\
\text { bölgenin de kendi içerisinde iş birliği içinde } \\
\text { oldukları sonucuna varılmıştır. }\end{array}$ \\
\hline $\begin{array}{l}\text { Bakan ve } \\
\text { Doğan (2012) }\end{array}$ & $\begin{array}{l}\text { Endüstrilerin rekabet gücü incelenmiştir. } \\
\text { Çalışma da Porter'ın Elmas Modeli } \\
\text { kullanılmış ve } 278 \text { işletme ile anket } \\
\text { görüşmesi yapılmıştır. }\end{array}$ & $\begin{array}{l}\text { Kahramanmaraş'ta önde gelen dört rekabetçi sektöre } \\
\text { anket uygulanmış ve rekabetçiliği; talep, devlet ve } \\
\text { faktör koşullarının en fazla etkilediği sonucuna } \\
\text { ulaşılmıstır. }\end{array}$ \\
\hline $\begin{array}{l}\text { Mevlana } \\
\text { Kalkınma } \\
\text { Ajansı } \\
\text { (MEVKA) } \\
(2012)\end{array}$ & $\begin{array}{l}\text { Huğlu silah sektörünün sorunlarının tespiti } \\
\text { ve çözüm önerilerine yer verilen çalışmada, } \\
\text { hazır veriler ve bazı işletmelerin görüşleri } \\
\text { sonucu Huğlu silah sektörünün analizi } \\
\text { yapılmıştır. }\end{array}$ & $\begin{array}{l}2012 \text { yılı itibari ile sektörün dünya ihracatında } 8 \text { ülke } \\
\text { içerisinde yer aldığı, başarısının giderek arttığı, bu } \\
\text { doğrultuda tespit edilen eksikliklerin eğitimlerle ve } \\
\text { devlet desteği ile sağlanmasıyla dünya pazarında } \\
\text { rekabet üstünlüğü sağlanabileceği rapor edilmiştir. }\end{array}$ \\
\hline $\begin{array}{l}\text { Çetin ve Kara } \\
(2008)\end{array}$ & $\begin{array}{l}\text { OSB bölgelerinin bölgesel kalkınmadaki } \\
\text { etkilerine bakılan çalışmada } 30 \text { işletme ile } \\
\text { anket görüşmesi yapılmıştır. }\end{array}$ & $\begin{array}{l}\text { Çalışma sonucunda Isparta OBS bölgesinin } \\
\text { kalkınmadaki fonksiyonunun etkin } \\
\text { değekilde } \\
\text { değlendirilemediği sonucuna ulaşılmıştır. }\end{array}$ \\
\hline $\begin{array}{l}\text { Koçak ve } \\
\text { Edwards (2005) }\end{array}$ & $\begin{array}{l}\text { Av tüfeği sektöründe iş birliği yapan } \\
\text { işletmelerle ve bağımsız işletmelerle anket } \\
\text { çalışması yapılmıştır. }\end{array}$ & $\begin{array}{l}\text { Huğlu'nun kümelenip iş birliğ ği yapmasının yeni işler } \\
\text { yaratıp refahı arttıracağı ve iş birliği yapan küçük } \\
\text { işletmelerin bağımsız işletmelerden daha fazla başarı } \\
\text { ve büyüme elde edeceği sonucuna ulaşılmıştır. }\end{array}$ \\
\hline
\end{tabular}

Tablo 1'de gösterildiği gibi, Huğlu-Üzümlü bölgesi incelenmiş, bölgenin analizi yapılarak önerilerde bulunulmuş, Mevlana Kalkınma Ajansı başta olmak üzere bir takım kurumlar da bölgenin katma değerinin arttırılması üzerine çalışmalar yürütmüştür. Diğer çalışmalardan farklı olarak bu araştırmada, büyük ölçekli işletmelerin yanında küçük ölçekli işletmelerin yetkilileri ile yüz yüze görüşmeler yapılarak, anket yoluyla birincil veriler elde edilmiştir. Diğer taraftan sektörel değerlendirmeye ek olarak, bölgesel iş birliği ve ticari ağlar da analiz edilmiştir.

\section{Yöntem}

\subsection{Araştırmanın Modeli}

Araştırmada amaca ulaşılabilmesi için ilişkisel tarama modelinden ve nitel araştırma yöntemlerinden yarı yapılandırılmış görüşmeden faydalanılmıştır.

\subsection{Evren ve Örneklem}

Araştırma evrenini Beyşehir Ticaret Odası'na kayıtlı toplam 190 işletme oluşturmaktadır. Araştırmanın örneklemini ise, Beyşehir ilçesinde av tüfeği imalatı, av tüfeği parça imalatı ve diğer destekleyici ürünlerin imalatını yapan işletmelerden 100 tanesi oluşturmaktadır. Bu 100 işletme SAA uygun olması açısından "kartopu örneklemesi" ile belirlenmiştir. Kartopu örneklemesinde sektördeki bir işletmeyle görüşüldükten sonra, görüşülen işletmenin bağlantıya sahip olduğu diğer işletmeler örnekleme dahil edilir (Gülpınar, 2013: 339).

\subsection{Veri Toplama Araçları}

Araştırmanın amacına yönelik olarak hazırlanan anket, Delil (2013) tarafından yürütülen "TRC2 (DiyarbakırŞanlıurfa) Bölgesi Kurumlar Arası İş Birliği Ağ Analizi" çalışmasında kullanılan anketten uyarlanmış, bölgenin kendine özgü yapısı ve problemleri ile yeniden düzenlenmiştir. Bu düzenlemeler ile anket sektöre uygun hale getirilmiş, Aksaray Üniversitesi İnsan Araştırmaları Etik Kurulu'nun 2020/03-20 protokol numarası ile onay alınmıştır. Veriler bu anket aracılığıyla Ocak - Mart 2020 tarihleri arasında yürütülen yüz yüze görüşmeler ile elde edilmiştir.

\subsection{Verilerin Analizi}

Anket 33 sorudan oluşmaktadır. 25 soru işletmelerin genel bilgilerinden; kalan 7 soru ise bölgenin ve kurumun ortaklık ve iş birliği düzeyi ile ilgili sorulardan oluşmaktadır. Son soru ise işletmelerin en fazla iletişim içerisinde oldukları işletmelerin bilgilerinden oluşmaktadır. Yarı yapılandırılmış görüşme tekniği kullanılarak 
sektörün eksiklikleri ve bu eksikliklerin giderilebilmesi için yapılması gerekenler tartışılmıştır. Araştırmada karma yöntem kullanılmış, böylece hem nicel hem nitel tekniklere birlikte yer verilmiştir. SAA için Pajek programı kullanılmıştır. Çok değişkenli istatistiksel teknikler SPSS programı aracılığıyla uygulanmıştır.

Araştırmada örneklem sayısı, araştırma evreninin yaklaşık yüzde 55'ini oluşturmaktadır. Bu, küçük ölçekli işletmelerin durumlarının da dikkate alınması açısından önem taşır. Diğer taraftan, yarı yapılandırılmış görüşme tekniğinin kullanılmış olması, araştırma bulgularının hipotezlerle sınırlandırılmaması ve gerekli yorum ve önerilerin de dahil edilmesiyle araştırma bulgularını derinleştirmesine olanak tanımıştır. Bölgede özellikle yan sanayi ürünlerinin üretimini yapan işletmelere ulaşılamamış olması sonuçları genellemede sınırlayıcı faktör olarak görülmektedir. Av tüfeği üretiminin Türkiye genelinde \%75'inin bölgeden sağlanıyor olması, kalan \%25'lik kısmının ise araştırma dışı bırakılmış olması da araştırmanın kısıtlarındandır.

Literatürde sektörler arası veya sektör içindeki firmaların ağ analizi yapıldığında, yoğunluk ve merkezilik ölçüleri arasında önemli farklılık tespit edilmiştir (Çilingirtürk, 2020; Delil, 2013). Araştırmada Huğlu-Üzümlü av tüfeği sanayisinde yer alan firmaların merkezilik ölçüleri karşılaştırılarak, literatüre katkı sağlanması hedeflenmiştir. Buna ek olarak firmalar; bulunduğu bölge, alt sektörleri, ihracat durumu, hedef pazarları, yurtdışı fuarlara katılım, işgücü ve iş birliği düzeyi açısından da karşılaştırılmıştır.

Araştırmanın hipotezleri şu şekildedir:

$\mathrm{H}_{1}$ : Bölgeler ve alt sektörler arasında istatistiksel açıdan anlamlı bir ilişki vardır.

$\mathrm{H}_{2}$ : Alt sektörler ve ihracat arasında istatistiksel açıdan anlamlı bir ilişki vardır.

$\mathrm{H}_{3}$ : Alt sektörler ve hedef pazarlar arasında istatistiksel açıdan anlamlı bir ilişki vardır.

$\mathrm{H}_{4}$ : Alt sektörler ve işgücü arasında istatistiksel açıdan anlamlı bir ilişki vardır.

$\mathrm{H}_{5}$ : Alt sektörler ve yurtdışı fuarlara katılım arasında istatistiksel açıdan anlamlı bir ilişki vardır.

$\mathrm{H}_{6}$ : Alt sektörler ve iş birliği düzeyi arasında istatistiksel açıdan anlamlı bir ilişki vardır.

$\mathrm{H}_{7}$ : Firmaların tüm derece merkezilikleri farklılaşmaktadır.

Hs: Firmaların yakınlık merkezilikleri farklılaşmaktadır.

H9: Firmaların arasındalık merkezilikleri farklılaşmaktadır.

\section{Bulgular}

Araştırmadan elde edilen bulgular, üç bölüm halinde özetlenmiştir. Öncelikle anket verileri doğrultusunda elde edilen işletmelerin genel özellikleri, kurumun ve bölgenin ortaklık ve iş birliği düzeyi değerlendirmeleri ve iş birliği önündeki engeller sözel olarak ifade edilmiştir. Ardından işletmeler arası iş birliğini gösteren sosyal ağ gösterilmiş ve işletmeler arasındaki güçlü aktörler sosyal ağ merkezilik ölçüleri yardımı ile elde edilmiştir. Son olarak anket verileri ve yarı yapılandırılmış görüşme neticesinde elde edilen bilgiler birlikte sunulmuştur.

\section{1. İşletmelerin Genel Özellikleri ve Sektör İçi İş Birliği Değerlendirmelerine İlişkin Bulgular}

Araştırma kapsamında 100 işletme bulunduğu için, işletme sayısı ile yüzdelik oran eşittir. Özel üretim önündeki engel ile işletmenin yapacağı yatırımın önündeki engel maddelerinde birden fazla seçeneğin işaretlenmesine olanak tanındığından bu maddelerde işletme sayısı, yüzdelik orana eşit değildir ve bu maddelerin yorumlanmasında işletme sayılarına ve seçenek sıralamalarına odaklanılmıştır. Anket verileri içerisinde cevabı belirtilmemiş yanıtlar da bulunmaktadır.

100 işletmenin Huğlu (35), Üzümlü (30) ve Beyşehir (35) arasında yaklaşık eşit olarak dağıldıkları görülmektedir. Sektör bazında bakıldığında işletmelerin yüzde 54'ü av tüfeği imal etmekte, yüzde 33'ü parça imal etmekte, yüzde 13'ü de diğer destekleyici kuruluşlarda yer almaktadır. Kuruluş tarihi açısından; işletmelerin yüzde 22'si 1997'den önce, yüzde 21'i 1997 ile 2006 arasında, yüzde 35'i 2007 ile 2015 arasında, yüzde $20^{\prime}$ si ise 2015 'ten sonra kurulmuştur. İşletmelerin yüzde 58'i hem pazarlama hem AR-GE departmanına sahiptir. İşletmelerin yüzde 33'ü 5 ve altında, yüzde 34'ü 6 ile 14 arasında, yüzde 5'i 15 ile 21 arasında, yüzde $24^{\prime}$ ü ise $21^{\prime}$ den daha fazla iş gücüne sahiptir. Savunma sanayisine işletmelerin yüzde $30^{\prime} u$ üretim yapmaktadır. İşletmelerden yüzde 25'i 5 bin altında, yüzde 32'si 5 bin ile 25 bin arasında, yüzde 15'i yaklaşık 25 bin ile 50 bin arasında ve yüzde $15^{\prime} \mathrm{i}$ ise 50 bin adetten fazla yıllık üretim yapmaktadır. İşletmelerden yüzde 69'u özel üretim yaptığını belirtirken, özel üretim önündeki en büyük engel olarak 54 işletme maliyet düzeyinin yüksek olmasını göstermiş, bunu talep yetersizliği (47) ve eğitimli eleman sayısının yetersizliği (31), kar marjının 
düşüklüğü (30) ve fabrikasyon üretime geçilmesi (26) takip etmiştir. İşletmelerin yüzde 65'i ihracat yapmakta ve yüzde $63^{\prime}$ ü dış pazarı, yüzde $27^{\prime}$ si iç pazarları, yüzde 10'u iç ve dış pazarları hedeflemektedir. İşletmenin yapacağ1 yatırımlar önündeki temel engeli; 66 işletme KDV-ÖTV düzeyinin yüksekliği olarak belirtmiştir. Bunu sırasıyla; döviz kurundaki dalgalanma (51), kalifiye iş gücü yetersizliği (29) ve talep yetersizliği (20) takip etmektedir. Geçtiğimiz yıla kıyasla işletmelerin yüzde 40'ı üretim miktarının arttığını, yüzde 39'u sipariş miktarının arttığını, yüzde $38^{\prime}$ i rekabet gücünün arttığını ve yüzde 76 'sı birim maliyetin arttığını belirtmektedir. Gelecek yıla ilişkin olarak da işletmelerin yüzde $66^{\prime}$ sı birim maliyet beklentisinin arttığını ve yüzde 35'i karlılık düzeyinin artmasını beklemektedir. İşletmelerin yüzde 35'i bölgedeki iş birliğinin normal düzeyde, yüzde 27'si iyi düzeyde, yüzde 13'ü çok iyi düzeyde ve yüzde 12'si yetersiz düzeyde olduğunu düşünmektedir. Kurumlar arası iş birliğinin önündeki engeller ise sırasıyla; finansal kaynakların kısıtlı olması (\%23), kişisel çıkarların kurumsal vizyonun önüne geçmesi (\%22), temel düşünce ayrılıkları (\%22), rekabet ortamı (\%15) ve kurumlar arası güvensizlik (\%8) olarak sıralanabilir. İşletmelerin yüzde 34'ü kurumlarının başka firmalarla iş birliği durumunun iyi düzeyde, yüzde 31'i normal düzeyde, yüzde 20 'si çok iyi düzeyde ve yüzde 1'i yetersiz düzeyde olduğunu düşünmektedir. Yüzde 1 işletme ise başka kurumlarla iş birliğinin olmadığını belirtmiştir. İş birliğini geliştirmek için işletmelerin önerileri ise şu şekilde sıralanabilir: Ortak proje sayısının arttırılması için toplantıların düzenlenmesi (\%38), kurumsal iş birliğinden sorumlu personelin görevlendirilmesi (\%19), ilgili kuruluşların görevlendirilmesi (\%15), iş birliği konulu bilgilendirmelerin yapılması (\%10) ve ortaklığın zorunlu olduğu destek programlarının yapılması (\%7). Diğer taraftan işletmelerin yüzde $29^{\prime}$ u bölgenin ortaklık ve iş birliği kültürünün Konya geneline göre daha iyi düzeyde olduğunu, yüzde 22'si ise çok iyi düzeyde olduğunu düşünürken, yüzde 23'ü fikri olmadığını, yüzde 15'i aynı düzeyde olduğunu, yüzde 8'i ise çok kötü düzeyde olduğunu düşünmektedir. İşletmelerin yüzde 31'i Huğlu ve Üzümlü arasındaki ortaklık ve iş birliği kültürünün normal düzeyde, yüzde 26 's yetersiz düzeyde, yüzde 14'ü iyi düzeyde, yüzde \%13'ü çok iyi düzeyde, yüzde 13'ü ise hiç bulunmamakta olduğuna işaret etmektedir. Mekansal büyüklüklerine göre değerlendirildiğinde; işletmelerin yüzde 27'si 150-499 m² arasında, yüzde 24'ü $150 \mathrm{~m}^{2}$ den az, yüzde 25'i 500 ile $1000 \mathrm{~m}^{2}$ arasında, yüzde 24'ü ise $1000 \mathrm{~m}^{2}$ den fazla büyüklüğe sahiptir. İşletmelerin yüzde 35'i 6 ile 15 arasında farklı ürün ürettiğini belirtirken, yüzde 26's1 5 ve daha az, yüzde 12'si 16 ile 24 arasında, yüzde 20'si 24' den fazla farklı ürün ürettiğini belirtmiştir. Diğer taraftan işletmelerin yüzde 31'i üretimde kullanılan ham madde ya da ara malını ithal etmektedir. İşletmelerden yüzde 49'u yurt dışında düzenlenen fuarlara katılmaktadırlar. Görüşülen işletmelerin işlerini büyütmek istedikleri ancak en büyük eksikliklerini sırasıyla; kalifiye iş gücü ve ara eleman yetersizliği (48 işletme), mekan darlığını (46 işletme) ve iş birliğinden yoksunluk (17 işletme) olarak gördükleri belirlenmiştir. Araştırmaya katılan işletmelerin istihdam rakamlarının sektörler bazında dağılımı incelendiğinde; av tüfeği imalatı yapan işletmelerde 1914, av tüfeği parça imalatı yapan işletmelerde 306, av tüfeği sektörünü destekleyici işletmelerde ise 102 kişinin istihdam edildiği görülmektedir.

Tanımlayıcı istatistiklerin dışında araştırma kapsamında sektöre dair genel özellikler arasındaki ilişkiler de incelenmiştir. Buna göre Tablo 2' de bölgeler ve alt sektörler arasındaki ilişki (H1) yer almaktadır.

Tablo 2. Bölgeler ve Alt Sektörler Arasındaki İlişki

\begin{tabular}{|c|c|c|c|c|c|c|c|c|}
\hline Bölge & \multicolumn{2}{|c|}{ Huğlu } & \multicolumn{2}{|c|}{ Üzümlü } & \multicolumn{2}{|c|}{ Beyşehir } & Ki-kare & $\mathrm{p}$ \\
\hline Alt sektör & $\mathrm{N}$ & Yüzde & $\mathrm{N}$ & Yüzde & $\mathrm{N}$ & Yüzde & 9,581 & $0,048^{*}$ \\
\hline Av tüfeği imalatı & 14 & 25,9 & 20 & 37,0 & 20 & 37,0 & & \\
\hline Parça imalatı & 15 & 45,5 & 5 & 15,2 & 13 & 39,4 & & \\
\hline Diğer & 6 & 50,0 & 5 & 41,7 & 1 & 8,3 & & \\
\hline
\end{tabular}

Ki-kare Bağımsızlık testi (Fisher düzeltmesi) * $p \leq 0,05$

Tablo 2'ye göre bölgeler ve alt sektörler arasında anlamlı bir ilişki elde edilmiş $(p \leq 0,05)$ ve H1 hipotezi kabul edilmiştir. Üzümlü ve Beyşehir bölgelerinde av tüfeği imalatı (\%37) daha yüksekken, Huğlu bölgesi daha çok parça imalatına $(\% 45,5)$ yoğunlaşmıştır. Tablodaki diğer önemli bilgi ise Üzümlü bölgesinde parça ve diğer yan sanayi ürünlerinin üretiminin çok düşük olmasıdır. Tablo 3'te alt sektörler ve işletmelerin ihracat yapma durumları arasındaki ilişki (H2) bilgisine yer verilmiştir. 
Tablo 3. Alt Sektörler ve İhracat İlişkisi

\begin{tabular}{|l|c|c|c|c|c|c|}
\hline \multirow{2}{*}{ Ilthracat } & \multicolumn{2}{|c|}{ Evet } & \multicolumn{2}{c|}{ Hayır } & Ki-kare & p \\
\cline { 2 - 5 } & $\mathrm{N}$ & Yüzde & $\mathrm{N}$ & Yüzde & \multirow{2}{*}{40,242} & \multirow{2}{*}{$001^{*}$} \\
\cline { 2 - 5 } Av tüfeği imalatı & 50 & 92,6 & 4 & 7,4 & & \\
\hline Parça imalatı & 13 & 39,4 & 20 & 60,6 & & \\
\hline Diğer & 2 & 16,7 & 10 & 83,3 & & \\
\hline
\end{tabular}

Ki-kare Bağımsızlık testi (Fisher düzeltmesi) * $p \leq 0,05$

Tablo 3'te görüldüğü gibi alt sektörlere göre ihracat durumu anlamlı düzeyde farklılaşmaktadır $(\mathrm{p} \leq 0,05)$ ve H2 hipotezi kabul edilmiştir. Av tüfeği imal eden işletmelerin büyük çoğunluğunun (\%92,6) ihracat yaptıkları görülürken, bu oran parça imalatı yapan işletmelerde yüzde 39,4 ve diğer işletmelerde 16,7 olarak gerçekleşmiştir. Tablo 4'te alt sektörler ve hedef pazar arasındaki ilişki (H3) gösterilmektedir.

Tablo 4. Alt Sektörler ve Hedef Pazar İlişkisi

\begin{tabular}{|c|c|c|c|c|c|c|c|c|}
\hline \multirow{2}{*}{$\begin{array}{l}\text { Hedef Pazar } \\
\text { Alt sektör }\end{array}$} & \multicolumn{2}{|c|}{ İç pazar } & \multicolumn{2}{|c|}{ Diş pazar } & \multicolumn{2}{|c|}{ İç ve diş pazar } & \multirow{2}{*}{$\frac{\text { Ki-kare }}{42,357}$} & \multirow{2}{*}{$\frac{\mathrm{p}}{0,001^{*}}$} \\
\hline & $\mathrm{N}$ & Yüzde & $\mathrm{N}$ & Yüzde & $\mathrm{N}$ & Yüzde & & \\
\hline Av tüfeği imalatı & 1 & 1,9 & 48 & 88,9 & 5 & 9,3 & & \\
\hline Parça imalatı & 17 & 51,5 & 13 & 39,4 & 3 & 9,1 & & \\
\hline Diğer & 99 & 69,2 & 2 & 15,4 & 2 & 15,4 & & \\
\hline
\end{tabular}

Ki-kare Bă̆ımsızlık testi (Fisher düzeltmesi) * $p \leq 0,05$

Tablo 4'e göre alt sektörler hedefledikleri pazar açısından anlamlı farklılık göstermektedir $(\mathrm{p} \leq 0,05)$ ve $\mathrm{H} 3$ kabul edilmiştir. Av tüfeği alt sektörünün daha çok $(\% 88,9)$ dış pazara yönelik üretim yaptığı görülmektedir. Bu bilgi ihracat oranlarıyla da desteklenmektedir. Parça imalatı yapan işletmeler ise daha çok $(\% 51,5)$ iç pazarı hedeflemektedir. Burada hem iç hem de diş pazarı hedefleyen işletmelerin sayısının az olması dikkat çekmektedir. Tablo 5'te ise alt sektörler ve iş gücü dağılımları arasındaki ilişki (H4) yer almaktadır.

Tablo 5. Alt Sektörler ve İş Gücü İlişkisi

\begin{tabular}{|c|c|c|c|c|c|c|c|c|c|c|}
\hline İş gücü & \multicolumn{2}{|c|}{5 ve altı } & \multicolumn{2}{|c|}{$6-14$} & \multicolumn{2}{|c|}{$15-21$} & \multicolumn{2}{|c|}{21 ve üzeri } & Ki-kare & $\mathrm{p}$ \\
\hline & $\mathrm{N}$ & Yüzde & $\mathrm{N}$ & Yüzde & $\mathrm{N}$ & Yüzde & $\mathrm{N}$ & Yüzde & 23,263 & $0,001^{*}$ \\
\hline Av tüfeği imalatı & 9 & 17,0 & 20 & 37,7 & 5 & 9,4 & 19 & 35,8 & & \\
\hline Parça imalatı & 15 & 48,4 & 12 & 38,7 & - & - & 4 & 12,9 & & \\
\hline Diğer & 9 & 75,0 & 2 & 16,7 & - & - & 1 & 8,3 & & \\
\hline
\end{tabular}

Ki-kare Bă̆ımsızlık testi (Fisher düzeltmesi) * $p \leq 0,05$

Tablo 5'e göre alt sektörler ile iş gücü sayısı arasında anlamlı bir ilişki vardır $(p \leq 0,05)$ ve $H 4$ kabul edilmiştir. Av tüfeği imal eden işletmelerin, parça imal edenlere ve diğer destekleyici kuruluşlara oranla (\%35.8) daha fazla iş gücüne sahip olduğu görülmektedir. Tablo $6^{\prime}$ da alt sektörler ve yurtdışı fuarlara katılım arasındaki ilişki (H5) görülmektedir.

Tablo 6. Alt Sektörler ve Yurtdışı Fuarlara Katılım İlişkisi

\begin{tabular}{|l|c|c|c|c|c|c|}
\hline \multirow{2}{*}{ Fuar } & \multicolumn{2}{|c|}{ Evet } & \multicolumn{2}{c|}{ Hayır } & Ki-kare & p \\
\cline { 2 - 5 } Alt sektör & $\mathrm{N}$ & Yüzde & $\mathrm{N}$ & Yüzde & \multirow{2}{*}{38,357} & \multirow{2}{*}{$0,001^{*}$} \\
\hline Av tüfeği imalatı & 42 & 77,8 & 12 & 22,2 & & \\
\hline Parça imalatı & 6 & 18,2 & 27 & 81,8 & & \\
\hline Diğer & 1 & 8,3 & 11 & 91,7 & & \\
\hline
\end{tabular}

Ki-kare Bağımsızlık testi (Fisher düzeltmesi) * $p \leq 0,05$

Tablo 6'ya göre alt sektörler ile yurtdışı fuarlara katılım arasında anlamlı bir ilişki vardır $(p \leq 0,05)$ ve H5 kabul edilmiştir. Av tüfeği imal eden işletmelerin yurt dışında düzenlenen fuarlara \%77,8, parça imalatı yapanlar $\% 18,2$ ve diğer destekleyici kuruluşlar ise $\% 8,3$ ile katılım göstermektedir. Parça imalatı yapan çoğu işletme ev altı atölyesi şeklinde dizayn edildikleri için bu sonuç normal görülmektedir. Tablo 7 'de ise alt sektörler ve iş birliği düzeyi arasındaki ilişki (H6) görülmektedir. 
Tablo 7. Alt Sektörler ve İş Birliği İlişkisi

\begin{tabular}{|c|c|c|c|c|c|c|c|c|c|c|}
\hline \multirow{2}{*}{ Alt sektör } & \multicolumn{2}{|c|}{$\mathrm{Az}$} & \multicolumn{2}{|c|}{ Normal } & \multicolumn{2}{|c|}{ İyi } & \multicolumn{2}{|c|}{ Çok iyi } & Ki-kare & $\mathrm{p}$ \\
\hline & $\mathrm{N}$ & Yüzde & $\mathrm{N}$ & Yüzde & $\mathrm{N}$ & Yüzde & $\mathrm{N}$ & Yüzde & \multirow[t]{4}{*}{3,452} & \multirow[t]{4}{*}{0,750} \\
\hline Av tüfeği imalatı & 8 & 17,4 & 19 & 41,3 & 14 & 30,4 & 5 & 10,9 & & \\
\hline Parça imalatı & 2 & 6,7 & 13 & 43,3 & 9 & 30 & 6 & 20 & & \\
\hline Diğer & 2 & 18,2 & 3 & 27,3 & 4 & 36,4 & 2 & 18,2 & & \\
\hline
\end{tabular}

Ki-kare Bă̆ımsızlık testi (Fisher düzeltmesi) * $p \leq 0,05$

Tablo 7'ye göre alt sektörler ile iş birliği düzeyi arasında anlamlı bir ilişki yoktur $(p>0,05)$ ve H6 reddedilmiştir.

\subsection{Sosyal A $\breve{g}$ Analizine İlişkin Bulgular}

İşletmeler arası iş birliğini gösteren ağın oluşturulabilmesi ve işletmeler arası bağlantıların elde edilebilmesi için, işletmelerin en fazla iş birliği içerisinde olduğu işletmelerden varsa beş tanesini yazması ve iş birliği derecesini az (1), orta (2) ve çok (3) olarak belirtmesi istenmiştir. Elde edilen ağ Şekil 1'de gösterilmektedir.

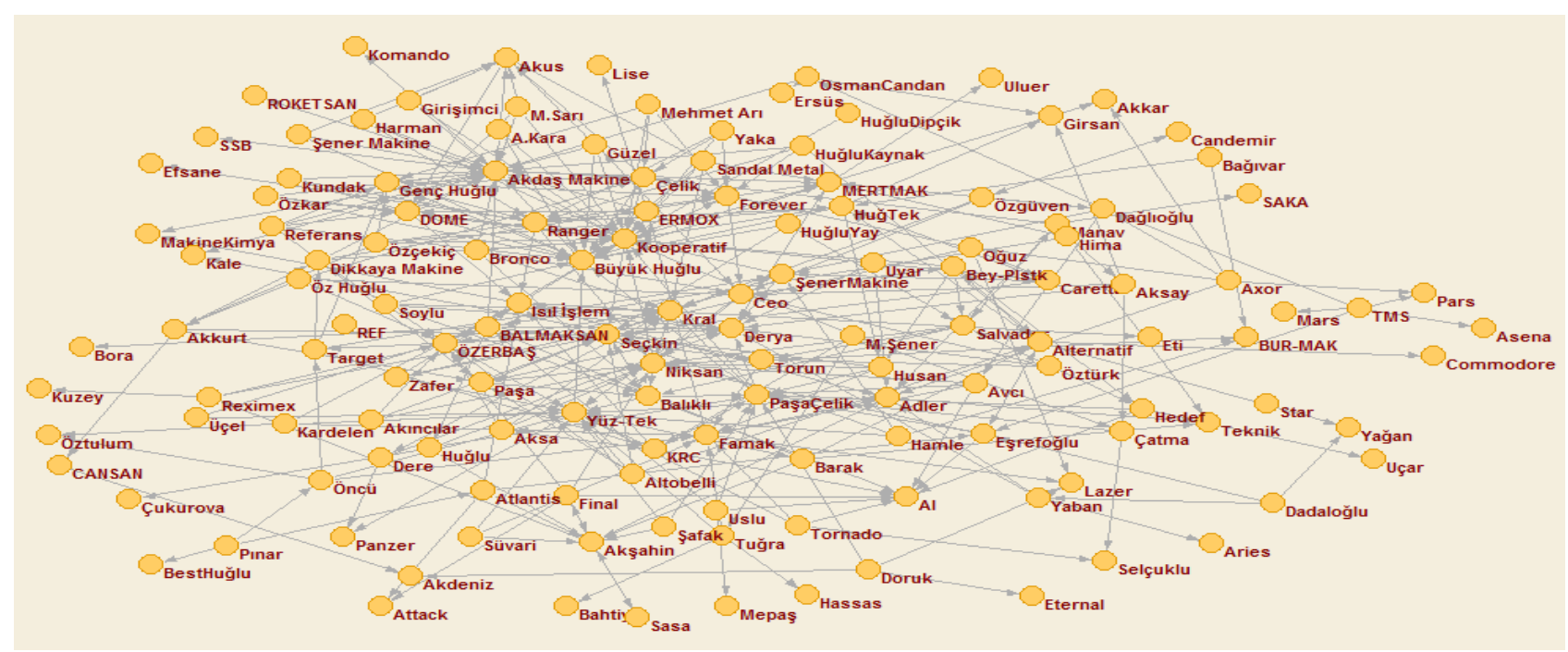

Şekil 1. Ağırlıksız İş Birliği Ağı

Şekilde 100 'den fazla işletme görünmektedir. Bunun nedeni araştırmaya dahil edilen işletmelerin iş birliği yaptığı bazı firmaların araştırma kapsamı dışında tutulmasıdır. Dolayısıyla bu firmalarda gelen bağlantılar mevcutken, giden bağlantılar mevcut değildir. Diğer bir deyişle ağın dışında kalan bu firmalarla iş birliği yapan işletmeler görünmekte, ancak bu işletmelerin hangi işletmelerle iş birliği yaptığ görünmemektedir. Araştırma kapsamına alınmayan ancak, işletmelerin iş birliği yapmaları dolayısıyla ağda yer alan bu firmaların, ağın merkezinin dışında kümelendikleri ve sadece gelen bağlantıları olduğu görülmektedir. Araştırma kapsamındaki 100 işletmenin ise hem iş birliği yaptığı hem de kendileriyle iş birliği yapan işletmeler görülmektedir. Şekil 1'de görüldüğü gibi bazı işletmelerin en fazla iş birliği yapılan işletmeler oldukları dolayısıyla merkezi konumda bulundukları, bazı işletmelerin ise daha zayıf bağlantılara sahip olduğu görülmektedir. Şekil 2' de ise iş birliğinin derecesini (yoğunluğunu) de gösteren ağırlıklı ağ yer almaktadır. 


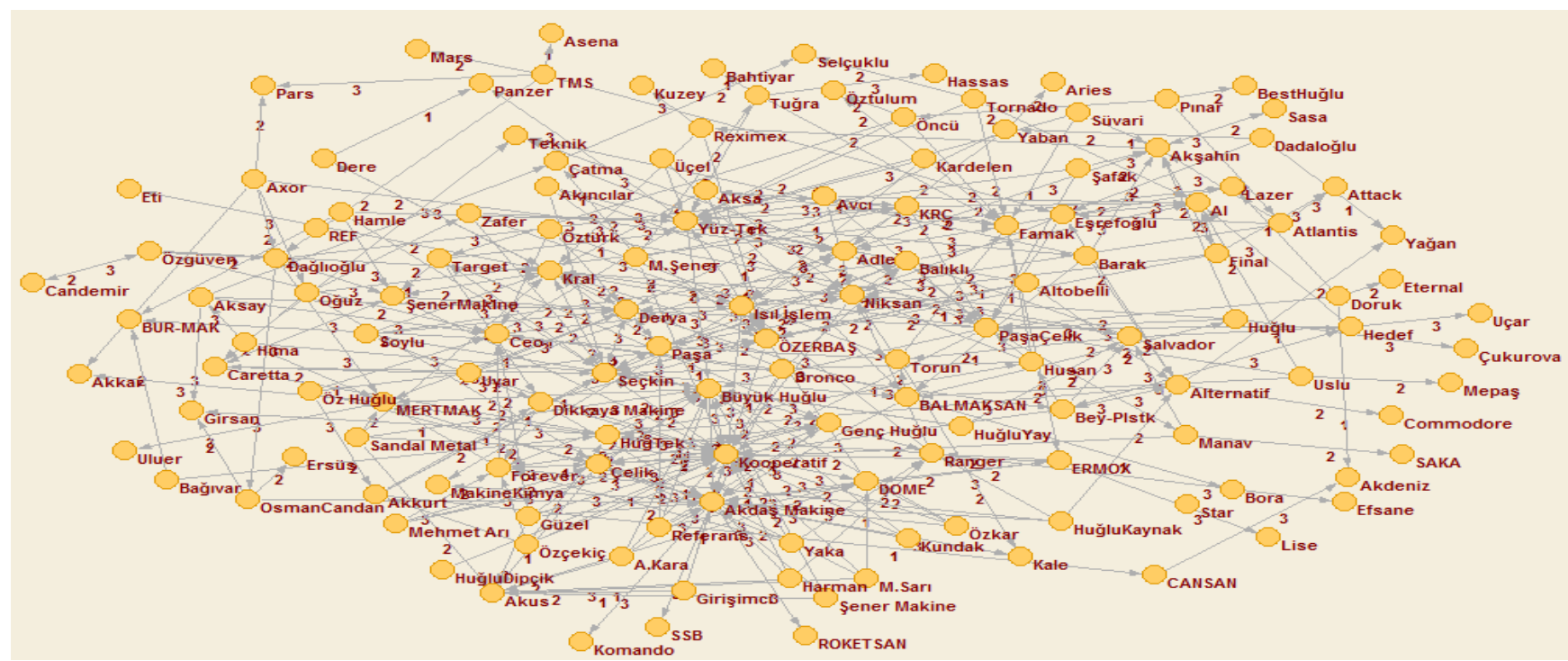

Şekil 2. Ağırlıklı İş Birliği A $\breve{g}_{1}$

Şekil 2'de Huğlu Av Tüfekleri Kooperatifi'nin (Kooperatif) ve Akdaş Makine Silah Sanayi'nin (Akdaş) ağda daha yoğun iş birliğine sahip oldukları görülmektedir. Şekil, bölgenin savunma sanayisi için üretime geçmesi ile ilgili olarak incelenebilir. Bu doğrultuda Huğlu bölgesinde Huğlu Av Tüfekleri Kooperatifi, Akdaş Makine Silah Sanayi ve Akus Silah Sanayi ile Üzümlü bölgesinden Derya Silah Sanayi, Aselsan Konya Silah Sistemlerinden ortaklık payı almış olmaları önemli bir gelişmedir ve ağdaki yoğun bağlantıların sebebi olarak açıklanabilir. Ağın yoğunluğu ise 0,0205 olarak elde edilmiştir. Ağların yoğunluğu farklı ağları karşılaştırmak için kullanılır (Gürsakal, 2009: 325). Sonuç bölümünde ağın yoğunluğu farklı çalışmalardaki ağlar ile karşılaştırılmıştır.

Şekil 2, sektör içerisindeki işletmelerin bağlantılarını ve bu bağlantıların gücünü göstermekte, ancak sadece görsel kolaylık sağlamaktadır. Ağın analizi için merkezilik ölçülerine de ihtiyaç duyulmaktadır. Tablo $8^{\prime}$ de derece merkezilikleri gösterilmiştir. Girdi derecesi diğer işletmelerin mevcut işletme ile yapılan iş birliğini gösterirken, çıktı derecesi işletmenin iş birliği yaptığı işletmeleri göstermektedir. Tüm derece merkeziliği ise girdi derecesi ve çıtı derecesinin toplamıdır.

Tablo 8. Sosyal Ağ Derece Merkezilikleri

\begin{tabular}{|l|c|c|c|}
\hline İşletme Adı & $\begin{array}{c}\text { Girdi Derece } \\
\text { Merkeziliği }\end{array}$ & $\begin{array}{c}\text { Çıtı Derece } \\
\text { Merkeziliği }\end{array}$ & $\begin{array}{c}\text { Toplam } \\
\text { Derece } \\
\text { Merkeziliği }\end{array}$ \\
\hline Huğlu Av Tüfekleri Kooperatifi & 28 & 5 & 33 \\
\hline Akdaş Makine Silah Ltd. Şti. & 21 & 5 & 26 \\
\hline Yüztek Yüzey Teknolojisi & 17 & 5 & 22 \\
\hline Büyük Huğlu Av Malz. San. Tic. Ltd. Şti. & 16 & 5 & 21 \\
\hline Kral Av Sanayi Müt.Trbbi Malz. San. ve Tic. Şti. & 14 & 5 & 19 \\
\hline Seçkin Savunma Silah İthalat İhracat San. & 14 & 3 & 17 \\
\hline Derya Silah Sanayi ve Tic. Ltd. Şti. & 13 & 4 & 17 \\
\hline Niksan Makine Savunma San. Tic. Ltd.Şti. & 13 & 3 & 16 \\
\hline Paşa Çelik San. Tic. Ltd. Şti. & 11 & 4 & 15 \\
\hline Famak Otomat & 10 & 4 & 14 \\
\hline
\end{tabular}

Tablo 6'da 100 işletme içerisinden derece merkezilikleri en yüksek ilk 10 işletme gösterilmektedir. Tabloya göre toplam derece merkeziliği en yüksek üç işletme; Huğlu Av Tüfekleri Kooperatifi, Akdaş Makine Silah Sanayi ve Yüztek Yüzey Teknolojileri olduğu görülmüştür.

Araştırma kapsamında, derece merkeziliğinin yanı sıra yakınlık ve arasındalık merkezilikleri de incelenmiştir. Tablo 9'da yakınlık merkezilikleri gösterilmektedir. 
Tablo 9. Sosyal A ğ Yakınlık Merkezilikleri

\begin{tabular}{|l|c|}
\hline İşletme Adı & Yakınlık Merkeziliği \\
\hline Huğlu Av Tüfekleri Kooperatifi & 0,454 \\
\hline Büyük Huğlu Av Malz. San. Tic. Ltd. Şti. & 0,429 \\
\hline Paşa Çelik San. Tic. Ltd. Şti. & 0,412 \\
\hline Niksan Makine Savunma San. Tic. Ltd.Şti. & 0,411 \\
\hline Akdaş Makine Silah Ltd. Şti. & 0,407 \\
\hline Yüztek Yüzey Teknolojisi & 0,406 \\
\hline Özerbaş Makine Silah Ot. İnşaat San. ve Tic. Ltd. Şti. & 0,395 \\
\hline Üzümlü Isıl İşlem Merkezi & 0,395 \\
\hline Seçkin Savunma Silah İthalat İhracat San. & 0,388 \\
\hline Kral Av Sanayi Müt. Tibbi Malz. San. ve Tic. Şti & 0,385 \\
\hline Derya Silah Sanayi ve Tic. Ltd. Şti. & 0,380 \\
\hline
\end{tabular}

Tablo 9'a göre yakınlık merkezilikleri en yüksek olan 3 işletme sırasıyla; Huğlu Av Tüfekleri Kooperatifi, Büyük Huğlu Av Malzemeleri ve Paşa Çelik Sanayi olmuştur. Tablo 10'da ise arasındalık merkezilikleri gösterilmektedir.

Tablo 10. Sosyal A $\breve{g}$ Arasındalık Merkezilikleri

\begin{tabular}{|l|c|}
\hline İşletme Adı & Arasındalık Merkeziliği \\
\hline Yüztek Yüzey Teknolojisi & 0,075 \\
\hline Adler Silah Sanayi & 0,068 \\
\hline Huğlu Av Tüfekleri Kooperatifi & 0,050 \\
\hline Büyük Huğlu Av Malz. San. Tic. Ltd. Şti. & 0,042 \\
\hline Barak Silah İnşaat San. İç ve Dış Tic. Ltd. Şti. & 0,040 \\
\hline Üzümlü Isıl İlem Merkezi & 0,039 \\
\hline Ceo Av Tüfeği İmalatı Arge San. Tic. A.Ş. & 0,034 \\
\hline Famak Otomat & 0,033 \\
\hline Akşahin Makine Sanayi & 0,032 \\
\hline Kral Av Sanayi Müt.Tibbi Malz. San. ve Tic. Şti & 0,031 \\
\hline
\end{tabular}

Tablo 10'a göre arasındalık merkeziliği en yüksek olan işletmeler sırasıyla Yüztek Yüzey Teknolojisi, Adler Silah Sanayi ve Huğlu Av Tüfekleri Kooperatifi'dir.

Araştırmaya katılan işletmelerin ağdaki konumlarının birbirlerinden ne derece farklılaştığı incelenmiştir. Bu amaçla, işletmelerin derece, yakınlık ve arasındalık merkezilikleri küçükten büyüğe sıralanmış ve iki gruba ayrılmıştır. İlk ve son grupların ortalamaları karşılaştırılmış, merkezilik ölçülerinin anlamlı düzeyde farklılaşıp farklılaşmadığı Tablo 11'de gösterilmiştir.

Tablo 11. Merkezilik Ölçülerinin Karşılaştırılması

\begin{tabular}{|l|c|c|c|c|c|c|}
\hline \multirow{2}{*}{ Merkezilik } & \multicolumn{2}{|c|}{ İlk grup } & \multicolumn{2}{c|}{ Son grup } & \multirow{2}{*}{$\mathrm{Z}$} \\
\cline { 2 - 6 } & Ortalama & Sıra Ort. & Ortalama & Sıra Ort. & & \\
\hline Tüm derece merkeziliğ $\mathrm{i}$ & 9,16 & 65,80 & 3,56 & 17,98 & $-7,772$ & $0,001^{*}$ \\
\hline Yakınlık merkeziliği & 0,354 & 102,49 & 0,281 & 34,51 & $-10,059$ & $0,001^{*}$ \\
\hline Arasındalık merkeziliği & 0,014 & 99,0 & 0,000 & 38,0 & $-9,896$ & $0,001^{*}$ \\
\hline
\end{tabular}

Tablo 11'e göre işletmelerin tüm derece merkeziliği, yakınlık merkeziliği ve arasındalık merkezilikleri birbirlerinden anlamlı düzeyde farklılaşmaktadır. Buna göre H7, H8 ve H9 hipotezleri desteklenmektedir. Ağda bazı işletmeler en etkili aktörler olarak yer alırken, bazı işletmeler ise ağın tamamen dışında kalmışlardır.

\subsection{Yarı Yapılandırılmış Görüşmeye İlişkin Bulgular}

Yarı yapılandırılmış görüşmede işletme yetkilileriyle hem anket soruları derinlemesine görüşülmüş, hem de anket sorularının dışında sektörde önemli gördükleri sorun, beklenti ve çözüm önerileri tartışılmıştır. 
Huğlu bölgesinde 1962'de başlayan av tüfeği üretimine Üzümlü ve Beyşehir'de kısa sürede dahil olmuş ve günümüze kadar yeni işletmeler eklenerek üretim sahası genişlemiştir. Huğlu da bulunan kooperatif; 387 çalışanı ile bölgede istihdamı en yüksek olan işletmedir ve üyeleri daha çok ev altı atölyelerinde parça imalatı ile fabrikayı destekler niteliktedir. Üzümlü ve Beyşehir'deki üretim merkezinin çokluğu ve parça imalatının azlığı ise üretim merkezlerinin gerekli tüm parçaları bünyelerinde üreterek, katma değerin işletme bünyesinde kalmasını hedeflenmesi ile açılanmaktadır.

Av tüfeği üretiminde isteğe göre binlerce farklı ürün üretilmektedir. Bazı işletmeler yurt dışından plastik ve yivli tüfek üretimi için namlu gibi ürünleri ithal etmekte, bunun dışındaki malzemeler yurtiçinden temin edilmektedir. Araştırmaya katılan işletmelerde toplam 2322 kişi istihdam edilmekte ve bunlardan 873 'ü çevre köylerde ikamet etmektedir. Sektörün gelişmesi, köylerdeki iç göçün önüne geçebilme potansiyeli açısından da önemli görülmektedir. Araştırmada 69 işletme yetkilisi özel üretim yapıldığını, ancak özel üretim maliyetlerinin çok yüksek olmasını üretim önündeki en büyük engel olarak gördüklerini ifade etmiştir. Maliyetlerinin yanı sıra özel üretimde uzmanlaşmış eleman eksikliği de diğer bir sorun olarak görülmektedir. Diğer taraftan işletmelerin yaklaşık yarısı yurt dışında düzenlenen fuarlara katılım sağladıklarını ve maliyetlerin karşılanmasında devlet desteğinin önemini vurgulamışlardır. Yurt dışında düzenlenen fuarlarda çok sayıdaki ülkenin kıyafet başta olmak üzere, optik, bıçak, fişek ve diğer av aksesuarlarını da pazarladıkları ve talebin fazla olduğu fakat Türkiye'nin sadece av tüfeği segmentinde yer aldığı tespit edilmiştir (KOP vd., 2019: 45-46). Bu alandaki yatırımların da arttırılması önerilmektedir. 63 işletme dış pazarları hedeflediğini belirtirken, ihracat önündeki en büyük engelin yasal prosedürler olduğu ifade edilmiştir. Parça üretimi ya da diğer destekleyici alanlarda hizmet veren işletmelerde 'markalaşma' en önemli problem olarak görülmektedir. İşletmeler büyümek istemekte, ancak kalifiye iş gücü ve ara eleman yetersizliği ile mekân darlığı en önemli engeller olarak görülmektedir.

İşletme yetkililerinin dikkat çektiği diğer bir husus ise nitelikli iş gücündeki yoksunluktur. Bölgede iş gücü yetiştirilmesi için lise ve yüksek okul düzeyinde ilgili programlar yer almakta, ancak yüksek mühendislik ve el işçiliği alanlarındaki eksiklik devam etmektedir. Mekân darlığı ise bölgenin coğrafi yapısından dolayı diğer önemli bir sorun olarak görülmektedir.

İşletmelerin yapacakları yatırımların önündeki en büyük engel vergi oranların yüksekliği olarak görülmektedir. Bölgede ki üreticilerin görüşüne göre; vergi oranları düşürülürse, herkes yasal düzenlemelere uygun olarak üretim yapacak ve devlet daha fazla vergi geliri toplayabilecektir (Konya Sanayi Odası, 2016: 30). İşletmeler, döviz kurundaki yükselişlerden dolayı maliyetlerin arttığını belirtmiş olmalarına rağmen, ortalama olarak gelecek yıl için üretim miktarlarının ve karlarının artacağını öngören iyimser bir görüş ileri sürmüşlerdir.

Diğer taraftan genel olarak bölgedeki ortaklık ve iş birliğinin normal düzeyde olduğu, iş birliği önündeki en büyük engelin finansal kaynakların kısıtlılığı olduğu ve iş birliğinin geliştirilmesi için ortak proje sayısının arttırılması amacıyla toplantıların düzenlenmesi gerektiği vurgulanmıştır. Huğlu'da böyle bir yapılanmayı sağlamak amacıyla HUSİAD (Huğlu Sanayici ve İşs insanları Derneği) kurulmuştur. Ayıca, genel olarak Konya geneline göre Huğlu-Üzümlü bölgesinde ortaklık ve iş birliği düzeyinin daha iyi olduğu belirtilmiştir. Huğlu'da işçilik ön planda iken Üzümlü'de pazarlama ön plana çıkmıştır.

Üretim kalitesinin arttırılabilmesi için ortak kullanıma açık AR-GE merkezleri, demir talaşlarının yeniden dönüştürülebilmesi için hattathane, hassas ölçümler için mastarhane, kromhane, 1sıl işlem ve nakliye işletmesi gibi kuruluşların bölge için yararlı olacağı üreticiler tarafından önerilmiştir. MEVKA'nın çalışmasında bölgede güneş enerjisi ve rüzgar gücünün hibrit olarak elde edilebileceği bir sistemin kurulması ve bölgenin ceviz ağacı türünden ağaçlandırılması gibi önerilere yer verilmiştir (Yalçın, 2016: 57).

Sektörün gelişmesinde, savunma sanayisine üretim gerçekleştirmenin önemi sıklıkla vurgulanmaktadır. Bu doğrultuda Aselsan Konya Silah Sistemleri'nden Huğlu-Üzümlü bölgesinden dört işletme (Huğlu Av Tüfekleri Kooperatifi, Akdaş Makine, Akus Silah Sanayi ve Derya Silah Sanayi) ortaklık payı almıştır. Üretimi yapılacak silahlar için öncelik hakkı tanınan bu işletmelerin bir kısmında fiili olarak üretim başlamıştır. Birçok büyük işletme de üretime başlayabilmek için mevcut faaliyet alanlarını genişletmek için gerekli fiziksel alt yapıyı sağlamaya çalışmaktadır. Savunma sanayisine silah üretimi yapabilmek için gerekli koşullardan biri olan tesis güvenliğinin sağlanması için de çalışmalar başlatılmıştır. Özellikle Huğlu bölgesinde savunma sanayisine üretim gerçekleştiriliyor olması, üreticilerin beklentilerini olumlu yönde etkilerken, Üzümlü ve 
Beyşehir bölgelerinde bazı işletmeler üretime geçmek üzere hazırlanmaktadır. Huğlu bölgesinde işletmelerin savunma sanayisine geçişleri ile beraber üretim artmış, işletmelerin üretim bandı yetersiz kalınca diğer işletmelerin desteğine ihtiyaç duyulmuş ve iş birliği artış göstermiştir. Bu doğrultuda savunma sanayisine üretimin geliştirilmesi ile; bölgedeki iş birliğinin ve üretici sayısının artması beklenmektedir.

Yarı yapılandırılmış görüşme değerlendirildiğinde, ülke içindeki taleplerin azaldığı fakat bunun yanında ihracat düzeyinin arttığı ve savunma sanayisine üretim yapmanın piyasayı canlandırdığı hâkim görüşlerdir.

\section{Sonuç ve Tartışma}

Huğlu-Üzümlü bölgesinde av tüfeği üretiminden, savunma sanayisine üretime geçişte sektördeki işletmelerin durumu değerlendirerek; işletmelerin ilişki ağı görselleştirip, sektörün önemli aktörlerinin belirlenmesi amacı ile bölgede saha araştırması yapılmıştır.

Çalışmada; bölgeler ve alt sektörler (H1), alt sektörler ve ihracat durumu (H2), alt sektörler ve hedef Pazar (H3), alt sektörler ve iş gücü (H4) ile alt sektörler ve yurt dışı fuarlara katılım (H5) arasında anlamlı ilişki bulunmuştur. Diğer taraftan firmaların tüm derece merkeziliği (H7), yakınlık merkeziliği (H8) ve arasındalık merkeziliği (H9) farklılaşmaktadır.

Yarı yapılandırılmış görüşme ile de desteklendiği gibi, bölgedeki işletmelerin iç piyasada beklenilen düzeyde satış yapamadıkları fakat ihracat yapan ve savunma sanayisine üretim gerçekleştiren işletmelerin bu durumdan ciddi düzeyde etkilenmedikleri görülmüştür. Özellikle savunma sanayisine fiili olarak üretime başlayan Huğlu bölgesinde; üretimler iş hacmini arttırmış ve büyüme fikri için itici güç olmuştur. Bölgenin coğrafi olarak dağlık bir yapıda olması ve bu durumun fiziksel gelişimin önünde engel olarak görülmesi, araştırmanın önemli diğer bir bulgusudur. Hali hazırda Huğlu ve Üzümlü bölgesi için iki ayrı sanayi sitesi projesi bulunmaktadır. Yapımına başlanan sanayi siteleri büyüklük olarak yetersiz olduğu için sadece küçük işletmelerin sanayi sitesine geçebileceği, büyük işletmelerin ise kendilerine özel alanlar tesis ederek büyümelerinin gerekli görüldüğü vurgulanmıştır. Bu amaçla çevre bölgelerde önemli büyük yatırımlar yapılmaktadır. Bazı işletmeler ise bölgede kalmanın iş gücüne ve destekleyici işletmelere yakınlık açısından daha yararlı olduğunu ancak büyümek için Beyşehir Organize Sanayi bölgesine gitmek zorunda kaldıklarını ifade etmişlerdir. Sürdürülebilir üretim için bölgenin sanayi sitesinden fazlasına ihtiyacı olduğu düşünülmekte, çözüm olarak bölgeye bir İhtisas Organize Sanayi yapılması önerilmektedir. Böylece işletmeler birbirine yakınlaşacak ve daha güçlü bir ağ elde edilecektir. Bölgenin üretim potansiyeli ve markalaşma gücü yüksektir. Bu yüzden yapılması önerilen İhtisas Organize Sanayi Bölgesi'nin Huğlu ve Üzümlü Bölgesine en yakın bir alana inşa edilmesi önerilmektedir. Böylece bölgenin marka değeri artarken göç yaşanmadan, bölge av tüfeğinde tamamıyla uzmanlaşabilir. Bölgedeki Selçuk Üniversitesi Huğlu Meslek Yüksekokulu'nda 2019 yılında eğitimi başlatılan silah teknikerliği bölümü ve Beyşehir Huğlu Makine Teknolojisi Mesleki ve Teknik Anadolu Lisesi'nde başlatılan projelerle bölgenin nitelikli iş gücü eksikliğinin giderilmesi hedeflenmektedir. Gravür üzerine eğitim veren yeni bölümlerin açılması da özel üretimin geliştirilmesi için önerilmektedir. İş gücü alımı için ortak bir havuzun oluşturulması da bu alandaki boşluğu doldurmak açısından önemli görülmektedir. Bölgede hammadde açısından benzerlik gösteren sağlık, otomotiv gibi endüstri malzemelerinin üretilebileceği ile ilgili öneriler de bulunmaktadır. Diğer taraftan sektörde kadın iş gücü sayısı görece çok sınırlı düzeydedir. Giyim üzerine açılacak iş kolu, kadın iş gücü sayısını da arttırma potansiyeline sahiptir.

Ağ analizi sonucunda ağın yoğunluğu 0,0205 olarak elde edilmiştir. Delil (2013), Diyarbakır- Şanlıurfa bölgesinde gönüllü iş birliği ağının yoğunluğunu 0,020, zorunlu iş birliği ağının yoğunluğunu 0,038, tüm ağın yoğunluğunu ise 0,045 olarak elde etmiştir. Benzer bir araştırmada Çilingirtürk (2020), Küçükçekmece ilçesinde makina sektörünün yoğunluğunu 0,014; sanayi sektörünün yoğunluğunu ise 0,009 olarak elde etmiştir. Farklı çalışmalarda incelenen sektörlerle karşılaştırıldığında, Huğlu-Üzümlü bölgesinde güçlü bir iş birliğinin olduğu söylenebilir. Bu iş birliğinin fiziksel olarak yakın işletmeler arasında daha güçlü olması dikkat çekmektedir. Merkezilik ölçüleri hesaplanmış; derece merkeziliği en yüksek 3 işletmenin; Huğlu Av Tüfekleri Kooperatifi, Akdaş Makine Silah Ltd. Şti. ve Yüztek Yüzey Teknolojileri olduğu ortaya çıkmıştır. 548 üyesi bulunan Huğlu Av Tüfekleri Kooperatifi uzun yıllardır alandaki hizmetlerini sürdürmektedir. 1962'den bu yana bölgedeki en etkili kurum olan Kooperatif, bölge için büyük bir gelir kaynağı olmuş, bölgede aynı dalda üretim yapan 190 işletmenin kurulmasına öncülük etmiş ve uzmanlaşma ile bölgenin dünyaca tanınmasına olanak tanımıştır. Av tüfeği üretiminde gerekli olan bazı yedek parçalar ev altında, fason üretim 
yapan bu küçük üreticiler tarafından karşılanır. Böylece katma değer bölge içerisinde kalırken, bölgede iş birliği düzeyi arttırılır. Akdaş Silah Sanayisi yoğun şekilde savunma sanayisine üretim yapmaktadır. Üretim için kullanılan yedek parçalar küçük işletmeler tarafından üretilmektedir. Yüztek Yüzey Teknolojiler ise krom kaplama işi yapmaktadır. Özellikle kendi bünyesinde bu işlemi yapamayan işletmelerin iş birliği kurmada zorunlu olduğu bir alandır. Bu durum, girdi derece merkeziliğinin yüksek olarak elde edilmesinin nedeni olarak görülmektedir.

Ağdaki bağlantıların ağırlıklarını da dikkate alan yakınlık merkeziliği en yüksek işletmeler ise sırasıyla; Huğlu Av Tüfekleri Kooperatifi, Büyük Huğlu Av Malzemeleri Sanayi ve Paşa Çelik Sanayi'dir. Bu işletmelerin ağda diğer işletmelerle daha hızlı etkileşim kurabildikleri anlaşılmaktadır. Arasındalık merkeziliği en yüksek işletmeler ise sırasıyla; Yüztek Yüzey Teknolojileri, Adler Silah Sanayi ve Huğlu Av Tüfekleri Kooperatifi'dir. Merkezilik sonuçlarından anlaşıldığ gibi bazı işletmelerin en fazla iş birliği yapılan işletmeler oldukları dolayısıyla merkezi konumda bulundukları, bazı işletmelerin ise daha zayıf bağlantılara sahip olduğu görülmektedir.

$\mathrm{Bu}$ çalışmada, işletmelerden yola çıkarak elde edilen bilgilerin sektörün bütününe genelleştirilmesinin yanı sıra iş birliği ve ortaklıkların da incelenmesinin önemi üzerinde durulmuştur. Teknolojik ilerlemelere paralel olarak iş birliği ve ortaklık, işletmeler ve sektörler arasında giderek daha fazla önem kazanmaktadır. Bu araştırmadan yola çıkılarak gelecek çalışmalarda farklı sektörlerde, sektör içi veya sektörler arası ağ analizleri ile daha gerçekçi ve derinlemesine bilgiler elde edilebilecektir.

\section{Kaynakça}

Bakan, İ. ve Doğan, İ. (2012). Competitiveness of the Industries Based on the Porte's Diamond Model: an Emprical Study, International Journal of Research and Reviews in Applied Science, 11(3), 441-455.

Basole, R.C. (2016). Topological analysis and visualization of interfirm collaboration networks in the electronics industry, Decision Support Systems, 83 (1), 22-31.

Cansız, M. (2010). Türkiye'de Organize Sanayi Bölgeleri Politikaları ve Uygulamaları, Ankara: DPT Yayınları. Erişim adresi content/uploads/2018/11/Turkiye_Organize_Sanayi_B\%C3\%B6lgeleri_

Politikalar\%C4\%B1_Uygulamalari.pdf

Çalışkan, V. ve Manav, K. (2014). Sanayi Coğrafyası Perspektifinden Huğlu (Beyşehir-Konya)'da Av Tüfeği Sanayii, International Periodical for the Languages, Literature and History of Turkish or Turkic, 9(11),149-69.

Çetin, M. ve Kara, M. (2008). Bir Kalkınma Aracı Olarak 'Organize Sanayi Bölgeleri' Isparta Süleyman Demirel Organize Sanayi Bölgesi Üzerine Bir Araştırma, Erciyes Üniversitesi İktisadi ve İdari Bilimler Fakültesi Dergisi, 31(1), 49-68.

Çilingirtürk, A. M. (2020). "İlçe Sanayi ve Ticaret Ağı ve Sektörel Analiz”, Gülpınar Demirci V. ve Çilingirtürk A. M. (editörler) Sosyal Ă̆g Analizi Yöntem ve İşletme Uygulamaları içinde. Bursa: Ekin Yayıncılık, 93-145.

Delil, S. (2013). "TRC2 (Diyarbakır-Şanlıurfa) Bölgesi Kurumlar Arası İşbirliği Ă̆g Analizi." Diyarbakır: Karacadağ Kalkınma Ajansı sayı: 2, s. 1-41.

Gülpınar, V. (2013). Yapay Sinir Ağları ve Sosyal Ağg Analizi Yardımı ile Türk Telekomünikasyon Piyasasında Müşteri Kaybı Analizi, Marmara Üniversitesi İIB dergisi, 34 (1), 331-350.

Gülpınar Demirci, V. (2020). “A $\breve{g}$ Bilimi”, Gülpınar Demirci V. ve Çilingirtürk A. M. (editörler) Sosyal A $\breve{g}$ Analizi Yöntem ve İşletme Uygulamaları içinde. Bursa: Ekin Yayıncılık, 7-89.

Gürsakal, N. (2009), Sosyal A ̆ Analizi, Bursa: Dora Yayınları.

ITC, (2019). Trade Map - List of Importing Markets for the Product Exported by Turkey in 2019, Erişim adresi https://www.trademap.org/Country SelProductCountry.aspx

Koçak, A. \& Edwards, V. (2005). Independence and Co-Operation Among Small Businesses: the Case of the Turkish Shotgun Industry in a Period of Recession, International Journal of Entrepreneurial Behavior \& Research, 11(3), 186-200. 
Konya Sanayi Odası (2016). “Darbe Engellendi Şimdi Sıra Daha Güçlü Ekonomide.” Lonca Dergisi, sayı:52, s.24-38.

MEB (15.5.2020). Konya Beyşehir Huğlu Makine Teknolojisi Mesleki ve Teknik Anadolu Lisesi. Erişim adresi https://www.meb.gov.tr/konya-beysehir-huglu-makine-teknolojisi-mesleki-ve-teknik-anadolulisesi/duyuru/16629

MEVKA (Mevlana Kalkınma Ajansı), (2012). Huğlu Av Tüfekleri Üretim ve Pazarlama Kapasitesinin Araştırılması, Mevlana Danışmanlık, Konya.

Müderrisoğlu, B. ve Gezici Korten, F. (2015). Mevcut Yığılmaların Kümelenmeye Dönüşümünde İlişkilerin Mekansal Dağılımı ve Yakınlık Olgusu, Planning, 25(2), 107-121.

On Birinci Kalkınma Planı 2019-2023, (2019). Strateji ve Bütçe Başkanlığı. Erişim adresi https://www.sbb.gov.tr/wp-content/uploads/2019/07/OnbirinciKalkinmaPlani.pdf

Rasskazov, S., Rubtcova, V., Derugin, P., Pruel, N., Malychev. V. (2016). Social Network Analysis as an Organizational Diagnostic Tool: The Case of Small Business in Russia, International Review of Management and Marketing, 6(1), 170-176.

Rojas, M.G.A., Solis, E.R.R. and Zhu, J.J. (2018). Innovation and network multiplexity: R\&D and the concurrent effects of two collaboration networks in an emerging economy, Research Policy, 47(6), 1111-1124.

STM ve KOP (2019). Huğlu ve Üzümlü Silah Sanayinde Katma Değerin Arttırılmasına Yönelik Eğitim ve Danışmanlık Projesi Nihai Rapor, Thinktech STM Teknoloji Düşünce Merkezi, Konya.

Yalçın, F. (2016). Huğlu Av Tüfekleri Üretimi Saha Araştırması Raporu, Konya: Mevlana Kalkınma Ajansı. Erişim adresi https://www.kalkinmakutuphanesi.gov.tr/assets/upload/dosyalar/dsy2fnr8a719201744632pm. pdf

Yaşar, A. (2019). "Huğlu Av Tüfeği Guinness Rekorlar Kitabı'nda", Erişim adresi https://www.aa.com.tr/tr/turkiye/huglu-av-tufegi-guinness-rekorlar-kitabinda/1662471 